\title{
Level of Knowledge and Attitudes of Pediatricians About Meningococcal Infections and Vaccination
}

\author{
Pediatristlerin Meningokok Enfeksiyonları ve Aşıları ile \\ İlgili Bilgi Düzeyleri ve Tutumları
}

\author{
Ulaş Özdemir', Tamer Çelik', Orkun Tolunay', Can Celiloğlu', Asena Sucu', Salim Reşitoğlu², Fahri Aydın², \\ Hüseyin Başpınar², Tuğçe Kazgan², Ümit Çelik \\ ${ }^{1}$ Clinic of Pediatrics, Health Sciences University, Adana City Training and Research Hospital, Adana, Türkiye \\ ${ }^{2}$ Clinic of Pediatrics, Adana Numune Training and Research Hospital, Adana, Türkiye
}

Abstract

Objective: Although meningococcal infections are most feared infectious diseases due to their high mortality and the possibility of leading to epidemics, there is no common practice for vaccination yet. In this study, we aimed to determine the level of knowledge about meningococcal infection and vaccination, and the attitude towards meningococcal vaccination among pediatricians.

Material and Methods: Participants were administered a 41-question survey, investigating the demographic properties, the knowledge on the meningococcal infection-vaccination and attitudes towards vaccination.

Results: The study enrolled a total of 169 participants (73 pediatrics specialists and 96 pediatric residents). Of the participants, $22.7 \%$ responded that meningococci (Neisseria meningitidis) was the most common cause of bacterial meningitis, while $99.1 \%$ of the participants agreed that the only reservoir in meningococcal infections was human, and $98.2 \%$ were contagious droplets. Participants stated that effective methods for protection from meningococcal infection were vaccination (81.1\%), droplet isolation (66.3\%), contact isolation (62.8\%) and postcontact chemoprophylaxis $(59.1 \%)$. While $40.7 \%$ of the participants reported that meningococcal vaccine recommended to all patients, $56.8 \%$ recommend to patients in the risk group, and $2.5 \%$ of respondents never suggested vaccination.

$81.8 \%$ of the participants agreed that the meningococcal vaccine to be included in the national childhood vaccination schedule. At a rate of $86.7 \%$, the participants had the idea that reduction of the vaccine costs would increase the vaccination frequency.
Özet

Giriş: Meningokok enfeksiyonları, yüksek mortalite ve epidemilere yol açabilmesi nedeniyle en korkulan enfeksiyon hastalıklarının başında geldiği halde henüz aşılama konusunda yaygın bir uygulama yapılamamaktadır. Bu çalışmamızda pediatri uzmanları ve uzmanlık eğitimi görmekte olan pediatri asistanlarının meningokok enfeksiyonu ve aşısı hakkındaki bilgi düzeyi ile meningokok aşısına yaklaşımlarını ölçmeyi amaçladık.

Gereç ve Yöntemler: Katılımcılara araştırmacılar tarafından hazırlanmış 41 soruluk bir anket uygulandı. Ankette katılımcıların demografik özellikleri ile ilgili sorular $(n=10)$, meningokok enfeksiyonu ile ilgili sorular $(n=10)$, meningokok aşısı ile ilgili sorular $(n=10)$ ve katılımcıların aşıya yaklaşımı ile ilgili sorular ( $n=11)$ bulunmaktaydı.

Bulgular: Anket formunu doldurup çalışmaya katılmayı 169 hekim kabul etti. Katılımcıların 73 (\%43.2)'ü uzman, 96 (\%56.8)'sı uzmanlık öğrencisi hekimdi. Bakteriyel menenjitlerin en sık etkeni sorusunu katılımcıların \%22.7'si meningokok (Neisseria meningitidis) olarak yanıtlarken, katılımcıların \%99.1'i meningokok enfeksiyonlarında tek rezervuarın insan olduğuna, \%98.2'si bulaşmanın damlacık yoluyla olduğuna katılmaktaydı. Katılımcılar meningokok enfeksiyonundan korunmada etkili yöntemlerin sırasıyla aşılama (\%81.1), damlacık izolasyonu (\%66.3), temas izolasyonu (\%62.8), temas sonrası kemoprofilaksi (\%59.1) olduğunu belirtmişlerdi. Katılımcıların \%40.7'si aşıyı tüm hastalarına, \%56.8'i risk grubundaki hastalarına önerirken, $\% 2.5^{\prime} \mathrm{i}$ ise hiç önermediğini bildirdi.

Katılımcıların \%81.8'i meningokok aşısının ulusal aşı şemasına girmesi gerektiğini düşünmekteydi. Katılımcıların \%86.7'si konjuge meningokok 
Conclusion: Besides the somehow low level of physicians knowledge about the vaccine, prejudices such the high cost of the vaccine or low frequency of the disease and thinking the vaccine to be ineffective have also been found to be effective against meningococcal vaccination. The immunization practices may improve with the increased of the level of knowledge and awareness of pediatricians about the menigococcal vaccine.

Keywords: Knowledge, meningococcal vaccine, pediatricians aşı maliyetlerinin düşürülmesinin aşılama oranlarını arttıracağını düşünmekteydi.

Sonuç: Hekimlerin bilgi düzeylerinden bağımsız olarak maliyet düşüncesi ya da hastalığın sıklığının az olduğu bu nedenle yaygın aşılamanın öncelikli olmadığı, aşının etkin olmadığı gibi önyargıların da meningokok aşısına karşı olmakta etkili olduğu görülmüştür. Hekimlerin yeni uygulamaya girmiş aşılar ile ilgili daha iyi bilgilendirilmeleri, özellikle meningokok enfeksiyonları ve aşılamasında ön saflarda çalışan pediatristlerin menigokok aşısı konusunda bilgi düzeylerinin ve farkındalıklarının artması ile aşı uygulamaları olumlu yönde etkilenecektir.

Anahtar Kelimeler: Farkındalık, meningokok aşısı, pediatrist

Polysaccharide and conjugated vaccines are used in the prevention of meningococcal diseases but the polysaccharide vaccines are not applied to the children below two years of age because the immune response they create is weak in children. In addition, these vaccines do not reduce the carrying rate of the disease and cannot create social immunodeficiency. Nowadays, conjugated vaccines are preferred rather than polysaccharide vaccines and polysaccharide vaccination is only recommended for those who are above the age of 55 among the patients with the indication of meningococcal vaccination $(7,10,11)$.

Conjugated vaccines include the conjugated meningococcal vaccines with single-component Serogroup $C$, single-component Serogroup A and 3 kinds of four-component $(A / C / Y / W)$ due to the different conjugating proteins and the vaccines that external membrane vesicles (OMV) and external membrane proteins are used for serogroup B (4CMENB).

There are 3 different four-component conjugated vaccines in our country (6). These are the vaccine linked to diphtheria toxoid protein (Menactra ${ }^{\circledR}$ ), the vaccine $\left(\right.$ Menveo $\left.^{\oplus}\right)$ linked to a cross-reacting material 197 (CRM197) with mutant diphtheria toxoid and the vaccine conjugated with tetanus Toxoid (Nimenrix $\left.^{\oplus}\right)(10,12,13)$. Meningococcal vaccine in our country is not included in the routine vaccination calendar.

Although meningococcal infections are the leading infectious diseases because they may cause high mortality and epidemics, the application of the vaccines is not widespread. In this study, we aimed to measure the approach to meningococcal vaccine and the level of knowledge about meningococcal infection and vaccination of pediatrists that are specialist or have majored in this field.

\section{Materials and Methods}

Participants joined a survey consisting of 41 questions prepared by the researchers. The questions included in the survey were about demographic characteristics of participants $(n=10)$, meningococcal infection $(n=10)$, the meningococcal vaccine $(n=10)$ and the participants' approach to vaccine $(n=$ 
11). The survey was prepared considering the similar studies in literature and the factors that may prevent the widespread application of meningococcal vaccine by the researchers. Participants were informed that the survey was conducted for scientific research and data that could reveal their identities were not collected. Survey forms were given to the participants to be filled by researchers and volunteers, and after the participants filled them without intervention, the survey forms were collected. In the survey; right-wrong, yes-no questions were addressed, as well as questions with multiple options for the participants to mark multiple choices.

The ethics committee approval was obtained from the "Adana Numune Training and Research Hospital non-interventional Clinical Research Ethics Board" for research.

\section{Statistical Analysis}

Statistical analysis was conducted with the program of Statistical Package for Social Sciences "version 20 (IBM Corp., Armonk, NY, USA). Descriptive statistics (number, percentage, average, and standard deviation) were calculated first of the variables in the workgroup. Then, comparative analyses were performed with Chi-square test. The significance limit is assumed to be $p<0.05$.

\section{Results}

\section{Demographic Findings of Participants}

169 physicians agreed to fill out the survey and participate in the study. 73 of the participants (43.2\%) were specialists, 96 $(56.8 \%)$ were specialty students. 88 of the participants were female $(52.1 \%), 81$ were male $(47.9 \%)$. The mean age of the participants was $32.24 \pm 7.04$ years. 107 of the participants (63.3\%) were married, $62(36.7 \%)$ were singles. 84 of the participants (49.7\%) had children, while 85 (50.3\%) had no child. 77 (45.6\%) of the participants performed their duty at the University Hospital, 35 (20.7\%), in Training and Research Hospitals, 24 (14.2\%) in State Hospitals, 33 (19.5\%) in private hospitals (Table 1).

\section{Information Level of the Participants' Meningococcal Infection}

The most frequent factor of bacterial meningitis was answered by $22.7 \%$ of the participants as Meningococcus ( $N$. meningitides), while $34.3 \%$ responded as Pneumococcus. $99.1 \%$ of the participants said that the single reservoir in meningococcal infections was human whereas $98.2 \%$ of the participants was through droplet. When the risk factors for meningococcal infection were asked; the splenectomy and immunodeficiency (92.8\%) were first ranked, the pilgrimage/travelling to risky areas was second with the rate of $77.8 \%$, infant age group was third with the rate of $68.3 \%$, overcrowded was forth with the rate of $64.7 \%$, viral upper respiratory tract infection was fifth with the rate of $28.4 \%$, and smoking was sixth with the rate of $24 \%$.
$35.2 \%$ of the participants thought that the permanent immune could be reached with a natural meningococcal infection. When the participants are asked about the most common meningococcal strains causing to invasive meningococcal diseases (IMD); W 70.8\%, A 48.2\%, C 36.5\%, X 36.5\%, B 35.5\%, Y $24.8 \%$, and non-typeable strains were marked at $16.1 \%$. When they were asked about the strains that cause IMD in our country; respectively, W 58\%, B 33.1\%, A 30\%, X 27.2\%, C 24.3\%, Y $16.6 \%$ and non-type strains were marked at $10.1 \%$. It was seen that whether the physicians were specialists or specialty students and that the type of hospital they were working did not make any statistically significant difference in answering these questions correctly. When the participants were asked about the effective methods to protect from meningococcal infection; the most frequently marked options, respectively; Vaccination $81.1 \%$, droplet insulation $66.3 \%$, contact isolation $62.8 \%$, Chemoprophylaxis after contact $59.1 \%$.

\section{Meningococcal Vaccine Information Level of the Participants}

While $87.6 \%$ of the participants knew that in our country there were two different types of vaccine, polysaccharide and conjugated, $12.4 \%$ thought it was a uniform vaccine. While 61.2 $\%$ of the participants agreed that polysaccharide vaccines could be performed over 2 years old, $38.8 \%$ of them thought polysaccharide vaccines could be made under two years of age. When they were asked about the age limit for conjugated vaccines; they said that: respectively; ninth month marked at $37.1 \%$, second month; $30.5 \%$, age of one; $21.9 \%$ and age of two $10.5 \%$. When they were asked about the strains contained in the conjugated vaccines used in our country, they marked the four-component (A/C/Y/W135) at $61.8 \%$, single component (c) at $35.5 \%$, single component (B) at $2.7 \%$.

Table 1. Demographical datas of participants

\begin{tabular}{|l|c|}
\hline & $\mathbf{n}(\%)$ \\
\hline Age (year) & $32.24 \pm 7.04$ \\
\hline Gender & $81(47.9)$ \\
\hline Male & $88(52.1)$ \\
\hline Female & $107(63.3)$ \\
\hline Married & $62(36.7)$ \\
\hline Single & $35(20.7)$ \\
\hline Worked hospital & $77(45.6)$ \\
\hline Training research & $24(14.2)$ \\
\hline University & $33(19.5)$ \\
\hline Public hospital & \\
\hline Private hospital & $96(56.8)$ \\
\hline Experience & $3(43.2)$ \\
\hline Specialist & \\
\hline Specialty student & \\
\hline
\end{tabular}




\section{Participants ' Approach to Meningococcal Vaccine}

When "Do you recommend Meningococcal vaccine to your patients?" was asked to the participants, $40.7 \%$ of physicians said that they recommended to all patients, and $56.8 \%$ of the patients in the risk group, while $2.5 \%$ of physicians did not recommend. This ratio was $45.8 \%, 51.4 \%$ and $2.8 \%$, respectively in specialists, while was $36.7 \%, 61.1 \%$ and $2.2 \%$ respectively for the specialty students. This rate was $69.7 \%$, $30.3 \%$, and $0 \%$ in the private hospitals, $8.7 \%, 38.2 \%$ in the state hospitals, $61.8 \%$ in the training and research hospitals and, $31.9 \%$ and $65.3 \%$ in university hospitals respectively. (Table 2). The participants who did not recommend the vaccine stated the reasons such as the high cost of the vaccine, then, respectively, side effects, the idea that the incidence of the disease was low and that the vaccine was not active. When "Would you get a meningococcal vaccine for your child" was asked to the participants (if any or if they were), the option Yes was selected at the rate of $80.1 \%$ while the question "Did you get a meningococcal vaccine for your child" the Yes option was marked at the rate of $51 \%$. While $39 \%$ of the participants said they had not get it because they thought the incidence of the disease was low, $29.9 \%$ stated the high cost of the vaccine, $20.3 \%$ stated the side effects, $6.8 \%$ stated they thought the vaccine was inactive and $23.8 \%$ stated other reasons.

$81.8 \%$ of all physicians ( $87.3 \%$ of the specialists and $77.7 \%$ of the specialty students) responded positively when they were asked whether they thought that meningococcal vaccine should enter the National vaccine Scheme $(p=0.111)$. When the participants who thought that the vaccine should not need to enter the national vaccination scheme were asked the reasons; $56.6 \%$ cited the high cost of the vaccine, $42.3 \%$ stated that it was not primary, $15.4 \%$ mentioned about the side effects and $7.7 \%$ stated that it was not active (Table 3 ).

When the participants were asked about the vaccines which should enter the national vaccine scheme as a priority, the route virus vaccine $(79.3 \%)$, the conjugated meningococcal vaccine (68.9\%), the HPV vaccine (44.2\%) were mentioned to be included in the national vaccine scheme.

As a reason for the non-widespread use of meningococcal vaccine, $57.8 \%$ of the participants stated the high cost of vaccination, $23.1 \%$ stated th side effects, $10.9 \%$ stated that it was not effective, $14.3 \%$ stated that mothers and fathers were against it, and $52.1 \%$ stated the lacking in education.

$86.7 \%$ of the participants thought the reduction of conjugated meningococcal vaccine costs would increase the vaccination rates. Expert physicians agreed to this idea at the rate of $93.1 \%$, while specialty students agreed at the rate of $81.7 \%$ $(p=0.034)$. There was no significant difference in the types of hospitals worked $p=0.252$ ).

\section{Discussion}

In this study, we aimed to measure the approach to meningococcal vaccine and the level of knowledge about meningococcal infection and vaccination of pediatrists who are one of the most effective groups in the vaccine applications.

In our study, $22.7 \%$ of the participants thought that Meningococcus was the most frequent factor of bacterial meningitis,

Table 2. Rate of the recommending the vaccine in terms of the hospital that are worked in

\begin{tabular}{|l|c|c|c|}
\hline & To all patients (\%) & To patients in risk group (\%) & Not-recommended (\%) \\
\hline Education research & 38.2 & 61.8 & 0 \\
\hline University & 31.9 & 65.3 & 2.8 \\
\hline Public hospital & 30.4 & 60.9 & 8.7 \\
\hline Private hospital & 69.7 & 30.3 & 0 \\
\hline
\end{tabular}

Table 3. Reasons of non-recommending the vaccine

\begin{tabular}{|l|c|c|c|}
\hline & General (\%) & $\begin{array}{c}\text { The ones don't approve to be } \\
\text { applied to their children }\end{array}$ & For national schema \\
\hline Cost & 53.6 & 29.9 & 56.6 \\
\hline Rarity of disease & 20.4 & 42.3 & 42.3 \\
\hline Side effects & 24.3 & 15.4 & 15.4 \\
\hline Less effect of vaccine & 9.3 & 6.8 & 7.7 \\
\hline Other & & 23.8 & 1.3 \\
\hline
\end{tabular}


while 55.2\% thought that Pneumococcus was the most frequent factor of bacterial meningitis. However, almost all participants (99.1\%) agreed that in meningococcal infections, the single reservoir was human and the contamination happned through the droplet (98.2\%).

When asked for risk factors for meningococcal infection; splenectomy and immunodeficiency were stated as primary rason $(92.8 \%)$ and the pilgrimage/travel to risky areas was second $(77.8 \%)$, as well as the other risk factors, noting that it was defined correctly over $60 \%$. Again, vaccination was selected as the most effective method in the prevention of meningococcal infection with the rate of $81.1 \%$.

As our study, in the literature, the comparison of the level of information about disease factors and disease could not be conducted because there were no publications on the knowledge and awareness levels of the physicians about the meningococcal diseases and its vaccines. But a recent study in our country has compared the awareness and attitudes of pediatrics and obstetrician and gynecologist on HPV infection and vaccines, and in this study, it has been seen that pediatrician specialists were not as knowledgeable as expected on HPV infection and HPV vaccine. However, their knowledge level does not have statistically significant difference with obstetrics specialists, and $59.5 \%$ of pediatrics recommends the HPV vaccine to patients (14). In our study, the level of knowledge about disease factors and disease was seen to be good.

When the $N$. meningitides strains, which are the most frequent factors in imd in our country, were asked, the participants said respectively; W 58\%, B 33.1\%, A 30\%, X 27.2\%, C 24.3\%, Y $16 \%$. There are 13 serogroups defined of the $N$. meningitis causing IMD, and the incidence of these serofactions varies according to regions and countries, and also the years. In various studies conducted in our country; serogroup $W$, serogroup $B$ and serogroup A were frequently seen, and after 2008 , serogroup $B$ was reported to be the leading serogroup (3-5).

In our study, $35.2 \%$ of the participants thought that permanent immunity was available for a lifetime. When we compared the group recommending the vaccine and the other group that the participants do not recommend the vaccine because the misunderstanding that the meningococcal vaccine may lead to a permanent immunity might cause some physicians not to recommend the vaccine to their patients, there was no statistically significant difference. In terms of this result, this information is no effective in recommending the vaccine.

The health workers and especially pediatricians have an important role in the national vaccine applications and recommendations. In Spain, in a study on the attitudes of families and health workers to new vaccine applications, $82.7 \%$ of pediatrists routinely educate the parents about vaccinations recom- mended for their children. $95 \%$ of the mothers and fathers saw the pediatrician as the most important source of information on immunization, and the parents who refrain from vaccination of their children tend to follow the advice of the doctor. It has been stated that the public awareness campaigns are needed in order to help the widespread acceptance of the changes in the vaccination programs as well as the health professionals will need strong professional advice (15).

Another study in Italy stated that serogroup B vaccine, which is a new application in their country, is largely recommended by pediatrists. In addition, it has been stated that the acceptance of this vaccine may increase with a special training program focused on increasing knowledge about prevention of meningitis and vaccination of the parents and health workers (16).

In addition, a special training program focused on increasing information about the prevention of meningitis and vaccination of parents and healthcare workers is indicated that the acceptability of this vaccine can increase (16).

In our study, the participants suggested meningococcal vaccines to their patients with a high rate of $97.5 \%$, while $2.5 \%$ of the participants did not recommend Meningococcal vaccine, as they said that the most reason was the high cost of vaccination. The factors affecting the vaccine applications and proposals in the world and in our country are investigated in various studies, and it has been found that even in developed countries, especially in the implementation of vaccines outside the national vaccine scheme, the height cost of the vaccine is the primary reason $(14,17-20)$. According to the evaluations on the basis of hospital studied, the pediatrists working in state hospitals do not recommend conjugated meningococcal vaccines at the rate of $8.7 \%$, and the ones in the private hospitals all recommend it.

When we considered the patient profile consulting to the State hospital and the socio-economic characteristics of the population who preferred private hospitals and the primary concern of physicians who do not recommend vaccinations, this result seems rational.

While the participants tended to recommend vaccines in general at a high rate of $97.5 \%$ (including the patients in the risk group and others), nearly half of the participants had vaccinated their children. Although it appears to be a low rate, a study conducted in Switzerland in 2005 reported that 31.9\% of pediatrics vaccinated meningococcal $C$ to their children and that this rate was more than non-pediatrics (21). In our country, this rate was reported as $44 \%$ for HPV vaccine (14).

In our study, $81.8 \%$ of the participants suggested that conjugated meningococcal vaccine would enter the national vaccine scheme. In the survey studies conducted for the meningococcal B vaccine in France and Germany, the pedia- 
trists recommended that these vaccines should be included in national schemes at high rates of $96.1 \%, 79 \%$, respectively $(20,21)$.

In the study conducted in India, in which the pneumococcus vaccine has not yet entered the routine vaccination scheme as of 2017, it was proposed that pneumococcus vaccine be included in the schema at the rate of $74 \%$ (19). In our country, this rate has been reported in the range of $60 \%-70 \%$ for HPV vaccine (14).

The reason proposed by the $56.6 \%$ of physicians who think that the vaccine does not need to enter the national vaccine scheme has been the higher cost of vaccination. It has also been shown in studies in various countries that the decisions taken in the national vaccine scheme for diseases that are less frequent face with difficulties, and the cost concerns are the most effective difficult in this matter (14,19,20,22-27). Also, the priority of entering national schemes in these studies conducted in our country and in the world is firstly the financial concerns and the second concern is the frequency of the illness $(14,19)$.

In our study, $42.3 \%$ of the participants who stated that the conjugated meningococcal vaccine should not enter the national vaccine scheme, thought that it was not primary; and they thought the vaccines that should enter this scheme is respectively, the route virus vaccine $(79.3 \%)$, the conjugated meningococcal vaccine (68.9\%), the HPV vaccine (44.2\%).

As in many studies, most of the participants $(86.7 \%)$ thought that the reduction of meningococcal vaccine costs would increase the incidence of vaccination $(14,19,20)$.

\section{Conclusion}

According to the some of the results of our study, due to physicians' low knowledge levels, as well as the cost of the vaccination or the incidence of the disease, widespread vaccination is not the primary, as the vaccine is not effective and prejudices against meningococcal vaccine are effective in this matter. The better informed of physicians and families especially regarding vaccines introduced into the new application will also positively affect vaccination rates in the target population (19,28-31).

Measures should be taken to increase the awareness and knowledge levels about meningococcal vaccination of the physicians who are the most effective factor in meningococcal infections and vaccination.

Ethics Committe Approval: Ethics committee approval was received for this study from the "Adana Numune Training and Research Hospital non-interventional Clinical Research Ethics Board" (02/10/2015. No: 194).
Informed Consent: Written informed consent was not obtained due to the retrospective nature of this study.

Peer-review: Externally peer-reviewed.

Author Contributions: Concept - UÖ, ÜÇ, OT, CC; Design - UÖ, OT, CC, TÇ, ÜÇ, AS; Supervision - UÖ, TÇ, ÜÇ, OT; Materials - UÖ, OT, CC, AS, SR, FA, HB, TK; Data collection and/or processing - UÖ, CC, AS, OT,SR, FA, HB, TK; Analysis and/or interpretation - UÖ, OT, TÇ, ÜÇ; Literature review - UÖ, CC, OT, ÜÇ, SR, FA, HB, TK; Writing - UÖ, OT, CC; Critical review - UÖ, ÜÇ, OT.

Conflict of Interest: No conflict of interest was declared by the authors.

Financial Disclosure: The authors declared that this study has received no financial support.

\section{References}

1. Özen M, Aslan N. Meningokok tarihçesi. Meningokok enfeksiyonları. Tanı, tedavi ve korunma. Ceyhan M (ed). 1. baskı. Ankara: Akademi Yayınevi, 2013:16-25.

2. Gianchecchi E, Piccini G, Torelli A, Rappuoli R, Montomoli E. An unwanted guest: Neisseria meningitidis - carriage, risk for invasive disease and the impact of vaccination with insight on Italy incidence. Expert Rev Anti Infect Ther 2017;15:689-701.

3. Kepenekli Kadayifci E, Güneşer Merdan D, Soysal A, et al. Prevalence of Neisseria meningitidis carriage: a small-scale survey in Istanbul, Turkey. J Infect Dev Ctries 2016;10:413-7.

4. Toprak D, Soysal A, Torunoğlu MA; Turkish Meningitis Study Group. $P C R$-based national bacterial meningitis surveillance in Turkey: years 2006 to 2009. Pediatr Infect Dis J 2014;33:1087-9.

5. Ceyhan M, Gürler N, Ozsurekci Y, et al. Meningitis caused by Neisseria Meningitidis, Hemophilus Influenzae Type $B$ and Streptococcus Pneumoniae during 2005-2012 in Turkey A multicenter prospective surveillance study. Hum Vaccin Immunother 2014;10:2706-12.

6. Özdemir H, Çiftçi E. Meningococcal vaccines. J Pediatr Inf 2014; 8:178-86.

7. Çelebi S. Prevention of bacterial meningitis. J Pediatr Inf 2014;8:33-9.

8. Skattum $L$, van Deuren $M$, van der Poll $T$, Truedsson $L$. Complement deficiency states and associated infections. Mol Immunol 2011;48:1643-55.

9. Arnold DF, Roberts AG, Thomas A, Ferry B, Morgan BP, Chapel H. A novel mutation in a patient with a deficiency of the eighth component of complement associated with recurrent meningococcal meningitis. $J$ Clin Immunol 2009;29:691-5.

10. Cengiz AB. Meningokok aşıları. Meningokok enfeksiyonları. Tanı, tedavi ve korunma. Ceyhan M (ed). 1. baskı. Ankara: Akademi Yayınevi, 2013:99-113.

11. Kara SS, Tezer H. Polisakkarit meningokok aşıları. Meningokok enfeksiyonlari. Tanı, tedavi ve Korunma. Ceyhan M (ed). 1. Baskı. Ankara: Akademi Yayınevi, 2013:114-21.

12. Centers forDisease Control and Prevention (CDC).Infantmeningococcal vaccination: Advisory Committtee on Immunization Practices (ACIP) recommendations and rationale. MMWR Morb Mortal Wkly Rep 2013;62:52-4.

13. Kimberlin DW, Brady MT, Jackson MA, Long SS. Meningococcal infections, American Academy of Pediatrics. Committee on Infectious Diseases; Red Book: 2015 Report of the Committee on Infectious Diseases. 30th edition. Elk Grove Village, IL: American Academy of Pediatrics, 2015:500-9. p 547-58. 
14. Tolunay $O$. Awareness and attitude relating to the human papilloma virus and its vaccines among pediatrics, obstetrics and gynecology specialists in Turkey. Asian Pac J Cancer Prev 2014;15:10723-8.

15. Bakhache $P$, Rodrigo $C$, Davie $S$, et al. Health care providers' and parents' attitudes toward administration of new infant vaccines-- $a$ multinational survey. Eur J Pediatr 2013;172:485-92.

16. Mameli C, Faccini M, Mazzali $C$, et al. Acceptability of meningococcal serogroup $B$ vaccine among parents and health care workers in Italy: $a$ survey. Hum Vaccin Immunother 2014;10:3004-10.

17. Niederhauser VP, Markowitz M. Barriers to immunizations: multiethnic parents of under- and unimmunized children speak. J Am Acad Nurse Pract 2007; 19:15-23.

18. Hak E, Schönbeck Y, De Melker H, Van Essen GA, Sanders EA. Negative attitude of highly educated parents and health care workers towards future vaccinations in the Dutch childhood vaccination program. Vaccine 2005;23:3103-7.

19. Zodpey S, Farooqui HH, Chokshi M, Kumar BR, Thacker N. Pediatricians' perspectives on pneumococcal conjugate vaccines: An exploratory study in the private sector. Indian J Public Health 2015;59:225-9.

20. Kempe A, Patel MM, Daley MF, et al. Adoption of rotavirus vaccination by pediatricians and family medicine physicians in the United States. Pediatrics 2009;124:e809-16.

21. Posfay-Barbe KM, Heininger U, Aebi C, Desgrandchamps D, Vaudaux B, Siegrist $C$. How do physicians immunize their own children? Differences among pediatricians and nonpediatricians. Pediatrics 2005;116:e62333.

22. Cohen R, Levy C, Bechet S, Elbez A, Corrard F. What do pediatricians and general practitioners think about the implementation of meningococal $B$ vaccination in France? Arch Pediatr 2012;19:1379-85.

23. Takla A, Wichmann O, Koch J, Terhardt M, Hellenbrand W. Survey of pediatricians in Germany reveals important challenges for possible implementation of meningococcal $B$ vaccination. Vaccine 2014;32:6349-55.
24. Pollard AJ, Christensen H. Trends in meningococcal disease: challenges for vaccine control when disease is rare. Med J Aust 2017;207:380-1.

25. Ortega-Sanchez IR, Meltzer MI, Shepard C, et al. Economics of an adolescent meningococcal conjugate vaccination catch-up campaign in the United States. Clin Infect Dis 2008;46:1-13.

26. Hepkema $H$, Pouwels KB, van der Ende A, Westra TA, Postma MJ. Meningococcal serogroup $A, C, W_{135}$ and $Y$ conjugated vaccine: a costeffectiveness analysis in the Netherlands. PLoS One 2013;8:e65036.

27. Lecoca H, Parent du Châtelet I, Taha MK, Lévy-Bruhl D, Dervaux B. Epidemiological impact and cost-effectiveness of introducing vaccination against serogroup $B$ meningococcal disease in France. Vaccine 2016;34:2240-50.

28. Borrow R, Caugant DA, Ceyhan $M$, et al. Meningococcal disease in the Middle East and Africa: Findings and updates from the Global Meningococcal Initiative. J Infect 2017;75:1-11.

29. Borrow R, Alarcón P, Carlos J, et al. The Global Meningococcal Initiative: global epidemiology, the impact of vaccines on meningococcal disease and the importance of herd protection. Expert Rev Vaccines 2017;16:313-28.

30. Moore PJ, Millar BC, Moore JE. Meningococcal ACWY vaccine uptake and awareness among student freshers enrolled at Northern Ireland universities. Int J Adolesc Med Health 2017. doi: 10.1515/ ijamh-2016-0087.

31. Al-Ghamdi AS, Kabbash IA. Awareness of healthcare workers regarding preventive measures of communicable diseases among Hajj pilgrims at the entry point in Western Saudi Arabia. Saudi Med J 2011;32:1161-7. 